\title{
EVA: LA MUSA SECRETA DE NERUDA EN «LAS FURIAS Y LAS PENAS»
}

HERNÁN LOYOLA

Universidad de Sássari, Italia

loyola@gmail.com

Hernán Loyola

(Talagante, Chile, 1930). Se graduó en el Instituto Pedagógico de la Universidad de Chile, en 1954 con una tesis sobre Canto general de Pablo Neruda, con quien había entablado amistad en 1952. Desde 1973, exiliado, vive en Italia en donde ha sido catedrático de la Universidad de Sassari. Su esfuerzo investigador está concentrado principalmente en Neruda: Ser y morir en Pablo Neruda (1967), antologías, artículos, ediciones, hasta la edición crítica de sus Obras Completas en cinco volúmenes (1999-2002) y la biografía Neruda. La biografia literaria (2006).

In memoriam

Prof. Dr. Alejandro Cotera

\section{RESUMEN}

La figura de Eva Fréjaville se convierte en la clave de indagación de otro tiempo de amor secreto de Pablo Neruda plasmado en su poesía. Esta mujer, esposa momentánea de Alejo Carpentier y después del pintor Alejo Carpentier, con enigmas de origen y de vida, es base para la reconstrucción de un tiempo de vanguardias y bohemia en el que, en 1934, en Madrid, conoció a Pablo Neruda: «La enemiga» del poema «Las furias y las penas» sería Eva Fréjaville pero, por encima de aquella relación fugaz, desde un recuerdo confesado por Pablo Neruda, se reconstruye un episodio de la vida del poeta y de las relaciones mantenidas por varios creadores. La historia nos abre una nueva lectura del citado poema.

Palabras clave: Neruda, Eva Frévaille, «enemiga», 1934, vanguardia.

\section{ABSTRACT}

The figure of Eva Fréjaville is the key to a secret love Pablo Neruda reflected in his poetry. At the time, this enigmatic woman was the wife of Alejo Carpentier and later married the painter Alejo Carpentier. Little was know of her origins and life, and this becomes the basis for the reconstruction of a time of vanguard and bohemia in 1934, when she met Pablo Neruda. «The Enemy» of the poem «Las furias y las penas» would be Eva Fréjaville, however, this short affair, confessed by Pablo Neruda, allows a reconstruction of that time period and the relationships with other artists. Thus, history opens up a new reading of the well known poem.

Key words: Neruda, Eva Fréjaville, enemy, 1934, vanguard.

\section{I. ¿Quién es la Enemiga?}

Termina 1934, año en el que queda un enigma por afrontar: el poema «Las furias y las penas», escrito ese año según Neruda. Acogido definitivamente por Tercera residencia en 1947, el texto ya había sido anticipado en 1939 por dos opúsculos: uno publicado en Chile (Nascimento, Santiago, mayo 1939, 29 páginas) y el otro en Argentina (Ediciones del Ángel Gulab,
Buenos Aires, octubre 1939, 24 páginas). El opúsculo chileno traía, precediendo al texto, la siguiente advertencia del autor:

En 1934 fue escrito este poema. Cuántas cosas han sobrevenido desde entonces! España, donde lo escribí, es una cintura de ruinas. Ay! Si con sólo una gota de poesía o de amor pudéramos aplacar la ira del mundo, pero eso sólo lo pueden la lucha y el corazón resuelto.

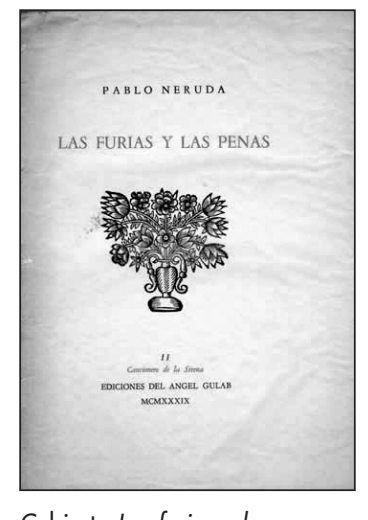

Cubierta Las furias y las penas.
Eva: la musa secreta de neruda en «Las furias y las penas» 


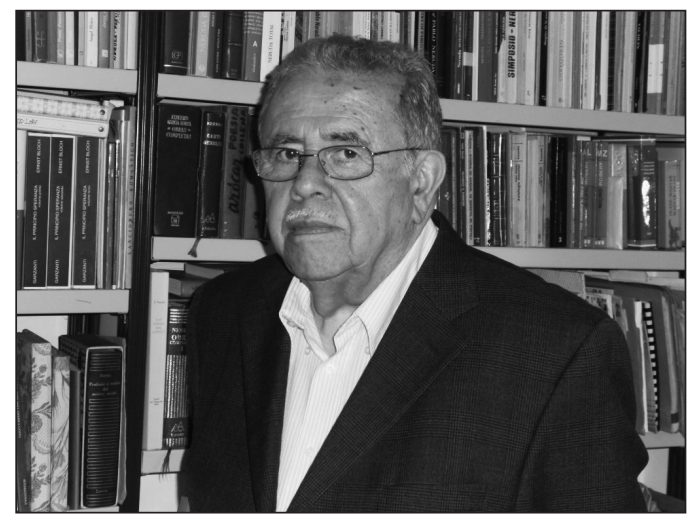

Hernán Loyola en su estudio.
El mundo ha cambiado y $\mathrm{mi}$ poesía ha cambiado. Juro defender hasta mi muerte lo que han asesinado en España: el derecho a la felicidad.

Marzo de 1939

El opúsculo argentino, algunos meses después, modificará así el segundo párrafo: «El mundo ha cambiado y mi poesía ha cambiado. Una gota de sangre caida en estas lineas quedará viviendo sobre ellas, indeleble como el amor». Esta modificada versión de la advertencia será la definitiva y aparece en todas las ediciones de Tercera residencia.

«Las furias y las penas» es un extenso poema de tema erótico que muestra afinidades estilísticas con algunos textos de Residencia en la tierra, por ejemplo con "Tango del viudo», «Barcarola» y «Oda con un lamento» por su enunciación intensamente apostrófica (una figura femenina es la destinataria interna del discurso), y con «Material nupcial» por el vehemente metralleo de imágenes conexas a la sexualidad. Pero en definitiva es un texto único y singular, sin parentesco próximo dentro del período, ni en extensión ni en sustancia temática.

Así como el «Poema 20» no es un poema de amor sino de nostálgico desamor, así en «Las furias y las penas» el amor se manifiesta como colérico y frustrado rencor, como mal celada recriminación por un desencuentro o por un despilfarro pasional que merecía mejor desenlace o destino. Tras el epígrafe de Quevedo (...Hay en mi corazón furias y penas...) reaparece -pudorosamente mimetizada como cita- la sinécdoque del tipo «plural por singular», frecuente en los títulos residenciarios («Enfermedades en mi casa», «Establecimientos nocturnos», "Melancolía en las familias»). Hay una sola y grande furia, mezcla de despecho y celos, provocada por una mujer evidentemente desinteresada en prolongar (o profundizar en exclusiva) una relación amorosa con el Sujeto enunciador del texto. Y una sola y grande pena porque evidentemente dicho Sujeto ha cargado esa relación con alguna fuerte esperanza, muy importante para él. ¿Por qué la dialéctica furia/pena en el terreno amoroso, nada rara en literatura, determinó en este caso un poema de extensión y vehemencia decididamente insólitas en el registro lírico del joven Neru$\mathrm{d} a$ ? A este enigma responde el poema mismo, según veremos.

Pero hay otro enigma (extratextual) que me intrigó por años hasta que, a fines de los 60 si no recuerdo mal, me atreví a interrogar derechamente al poeta en Isla Negra: «Pablo, ¿quién es la mujer en el trasfondo de «Las furias y las penas»?» Neruda llegó a España a mediados de 1934 con Maruca y a poco andar inició con Delia del Carril una relación entusiasta que durará veinte años. Basta leer el poema para establecer que ninguna de las dos pudo haber inspirado la figura femenina allí apostrofada como enemiga («Tú mi enemiga de tanto sueño roto... enemiga de grandes caderas»).

¿Maruja Mallo, entonces? Pero la pintora gallega -candidata bien posible, dadas su fuerte personalidad y sus costumbres muy poco convencionales para el país y para la épocahabría comenzado a frecuentar a Pablo en la Casa de las Flores sólo a comienzos de 1935, y en todo caso la relación entre ambos, aunque al parecer no excluyó el sexo ocasional, fue siempre más amistosa y cordial que erótica. Eran demasiado diversos. Talvez por eso no se sabe de ningún conflicto entre ellos.

Hay además un problema de tiempo. El tono y la tensión del contenido del poema presuponen una relación más o menos prolongada entre los personajes, aunque los contactos hayan sido intermitentes. Pero durante la segunda mitad de 1934 la búsqueda de casa en Madrid, los encuentros con Delia y con los amigos en Cervecería Correos y donde los Morla Lynch, la desdicha por Malva Marina, el octubre asturiano y sus secuelas, el recital con Federico en la Universidad, y además las tareas consulares y la escritura de varios poemas, difícilmente dejaron a Pablo mucho tiempo y ocasiones favorables para otra relación extraconyugal. Y de haberla, no habría pasado inadvertida. Se sabría, en suma.

Ahora bien, la respuesta de Neruda a mi pregunta de los años 60 (¿quién era, en la realidad extratextual, la figura femenina de «Las furias y las penas»?) no pudo ser más sorprendente e inesperada. Tras unos segundos de silencio y sin mirarme: «la mujer de Carpentier», me dijo. No agregó nada más y yo, infelizmente, no osé pedirle más detalles, ni siquiera el nombre ni la ocasión, y me limité
"Las furias y las penas"
LERNAN LOYOLA

HERNÁN LOYOLA 
a almacenar en mi memoria la confidencia recibida. Por supuesto, no tengo absolutamente ninguna duda de que Pablo me dijo la verdad. Por experiencia y verificaciones, sé que el poeta no mentía en cosas importantes. Y él sabía que tarde o temprano yo iba a publicar el secreto que me había confiado.

Aunque Neruda no me pidió discreción, hasta los últimos meses de 2010 nunca comuniqué a nadie su respuesta. Entre otras razones porque esperaba poder contextualizarla por mi cuenta y, no por último, porque Alejo Carpentier aún vivía. (Por entonces yo ignoraba que sólo en 1941 había desposado a Lilia Esteban, y confieso haber pensado, en un primer momento, que Pablo aludía a ella). No hay constancia de que alguien más haya hecho a Pablo la pregunta que yo le hice, ni de que él haya comunicado la misma información a otra persona, lo cierto es que el lector deberá confiar en mi palabra porque no puedo citar más fuente que mi propia memoria.

Puesto a investigar el tema, sólo un ensayo de Carmen Vásquez (1980) me ha procurado datos bastante minuciosos sobre la vida y actividades del Carpentier parisién de 19281939, pero sin mencionar a ninguna mujer. Fatigando papeles y google, y tras consultar a algunos especialistas que gentilmente me han ayudado (Roberto González Echevarría, Selena Millares y la misma Carmen Vásquez), concluyo que para dar nombre a «la mujer de Carpentier» en 1934 hay dos opciones: una se llama Maggie, la otra Eva. Descarto a Maggie -suiza o cubana que era la pareja de Carpentier cuando éste se instaló en París en 1928porque en 1934 se encuentra en un sanatorio de los Pirineos, enferma de tuberculosis desde hace ya algún tiempo. Sólo queda Eva.

\section{Eva Fréjaville}

Se trata de Eva Fréjaville, francesa nacida en 1913 y fallecida en 1998 a los 85 años (según Enrico Mario Santí: entrevista de 1992 publicada en 2005). Eva, con la E de Enigma desde el comienzo: ¿era de verdad la hija -no sólo en sentido legal- de Gustave Fréjaville, crítico de teatro y arte muy apreciado por los escritores y artistas del surrealismo parisién, o era una «posible hija natural de Diego Rivera» según Luisa Campuzano (2006) y también, como veremos, según Roberto González Echeverría (2008) y Graziella Pogolotti (2006)?
Carpentier se conecta a través de su amigo Robert Desnos con este círculo de intelectuales... y con Eva, entonces una adolescente de 14-15 años que cuando cumpla algunos más devendrá su amante -con ligamen más bien fluido- hasta 1939, año en que ambos, para eludir la gran guerra inminente en Europa, se trasladan juntos a La Habana donde se casan apenas desembarcados. Pero este primer matrimonio de Carpentier dura sólo un mes porque Eva renace y resplandece en el trópico y se enamora del pintor surrealista Carlos Enríquez, a cuyas sonadas fiestas en El Hurón Azul, su residencia-estudio, los recién casados habían acudido con fatal frecuencia:

El asunto de sus matrimonios es un punto neurálgico en Carpentier. Sabemos, y hay fotografías en Carteles que lo comprueban, que Carpentier regresó a Cuba en 1939 acompañado de Eva Fréjaville, identificada en una de las fotos como su "prometida» (18 de junio, 1939). Hoy sabemos también, es cierto que por rumores no verificados («radiobemba» como es conocida en Cuba la red chismográfica) que Fréjaville era hija ilegítima del pintor mexicano Diego Rivera con una francesa casada [que sería Zizou, la esposa de Gustave Fréjaville], y que a poco de llegar a Cuba dejó a Carpentier por el pintor Carlos Enríquez. Todo esto ocurría en el contexto del grupo vanguardista que se reunía en el Hurón Azul, casa del pintor que es hoy un museo. (González Echevarría, 2008, p. 29).

Confirmando indirectamente a González Echevarría, la biografía de Carlos Enríquez escrita por Juan Sánchez (La Habana, dos ediciones: 1996 y 2005) evita aludir al fugaz matrimonio Carpentier-Fréjaville y a la relación precedente en París. Véase por ejemplo cuán bruscamente el relato introduce a la francesa en la capital cubana y en qué modo ambiguo y reticente alude al triángulo:

Durante las visitas surgió la invitación para que Eva Fréjaville posara para un retrato que pintaría Carlos. Eva, recién llegada a Cuba en 1939, era una típica joven intelectual francesa, lectora devota de Marcel Proust, vivaracha y sensual, movida por una enorme avidez de disfrutar a plenitud la vida. / Algunos testimonios afirman que Eva se paseaba por París, donde la conoció Carpentier, con un cachorro de león. / Viajó con el novelista a La Habana y durante los primeros meses se alojó en el hotel Manhattan, en la calle Belascoaín, cerca del malecón. Carlos, retratista formidable, comenzó a pintar a Eva Fréjaville en El Hurón y, a veces, cuando Carpentier pasaba a

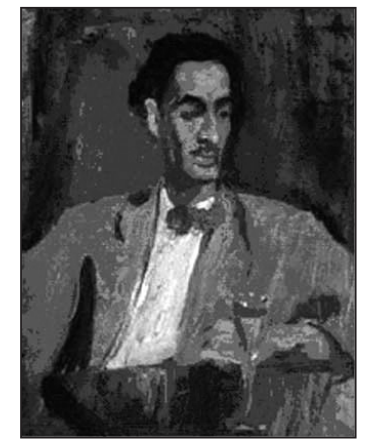

Carlos Enríquez, visto por su primera esposa Alice Neel, 1926.
Eva: la musa secreta de neruda en «Las furias y las penas» HERNÁN LOYOLA 


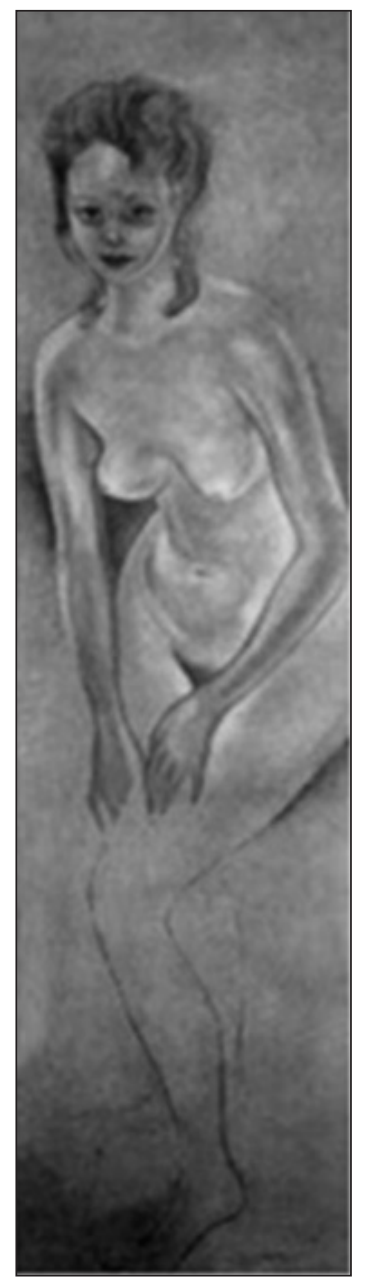

Eva Fréjaville, de Carlos Enríquez.
Eva: la musa secreta de neruda en «Las furias y las penas» HERNÁN LOYOLA recogerla, los tres salían a recorrer La Habana en un automóvil que entonces poseía el pintor» (Sánchez, 2005 , p. 125).

Tal vez no sea responsabilidad del autor que un par de páginas más adelante, sin explicación alguna, la joven francesa aparezca «raptada», así: «A partir del «rapto» de Eva los asiduos a El Hurón se dividieron. Unos continuaron asistiendo a las veladas dominicales y otros dejaron de asistir. A los pocos meses, Carlos y Eva se casaron. Sirvieron como testigos de la boda Roldán Capaz, Pablo Porras -recién llegado a La Habana- y un chino que Carlos Enríquez mantenía en la finca para que cocinara y cuidara de una pequeña huerta» (Sánchez, 2005, p. 127).

¿Rapto de Eva? O yo me distraje y lo pasé por alto, o el relato del «rapto» mismo, con sus actores y circunstancias, desapareció del original. Una nota anónima que reproduzco desde Internet (podría ser de Graziella Pogolotti) nos entrega información al respecto:

El gran amor de Carlos fue la parisina Eva Fréjaville, escritora que creyó encontrar en el trópico la savia intelectual. Pero su vida, gracias a sabe Dios qué misterio entre piernas, se hizo centro de un torbellino erótico. Primero, fue amante de Alejo Carpentier, quien la presentó al pintor en un convite en El Hurón Azul. Precisamente, en una de las bacanales en los predios de Carlos, se inició el flirt clandestino con Eva que culminó con un rapto público en el Malecón evadiendo los disparos del revólver de Carpentier. El autor del Viaje a la semilla nunca más pisaría El Hurón Azul.

Una versión diferente del episodio trae Marcelo Pogolotti, muy amigo del pintor, en sus memorias Del barro y las voces (1968), donde refiere que

Carlos Enríquez llegó [a visitarlo] con muchos aspavientos y declaraciones despampanantes sobre su reciente aventura, el rapto de Eva Fréjaville, la mujer de Carpentier, y lo invitó a su casa de las afueras de La Habana -el mítico «Hurón Azul»- para que conociera a la blonda heroína del drama que acababa de protagonizar. Era una típica joven intelectual francesa, izquierdista de salón, lectora devota de Marcel Proust, emancipada, muy à la page, vivaracha, sensual y movida por una desenfrenada avidez de disfrutar a plenitud la vida, caldeada sin duda por el decorado tropical, ya que el gusto por el exotismo alucina a los franceses. Gárrula y estridente, pero bien dotada de inteligencia y cultura, parecía excitada por el aire y la intimidad campestres (Pogolotti, M. 1968, pp. 267-268).

Tras algunos comentarios sobre el escándalo suscitado, líneas más abajo Pogolotti refiere la versión del «rapto» según Enríquez:

Los tres iban en un automóvil, y en pleno Malecón, a la luz del día, Carlos frenó, preguntándole a Eva si prefería seguir con Alejo o irse con él, y al contestarle ella que esto último, invitó al amigo a que bajara del vehículo. Cuando Carpentier, pensando que se trataba de una broma, fue a El Hurón Azul, el pintor esgrimió teatralmente un revólver. (Pogliotti, M., 1968)

Durante la mencionada entrevista Enrico Mario Santí (2005) obtiene de Eva significativas respuestas acerca de su relación con Carpentier:

EMS: Antes de casarse con usted, ¿Carpentier ya se había casado?

EVA: Carpentier se casó una sola vez conmigo. Dijo que se había sido casado con una mujer llamada Maggie. Pero sólo vivió con ella, y nunca se casaron. EMS: ¿Maggie era suiza?

EVA: Sí. Salían mucho, estaba siempre con Maggie en París. Todo el mundo le decía Madame Carpentier, pero nunca se casaron.

EMS: ¿Usted la conoció?

EVA: Sí, cómo no, era buena gente. Pero se enfermó de tuberculosis y se fue de París. Ahí él también me mintió mucho. Me dijo que había terminado con ella y yo creo que no lo hizo. Yo no era el tipo de mujer que habría andado con él si hubiera andado con otra; no soy el tipo de persona para engañar a nadie con adulterios o intrigas. El me mintió mucho, me dijo que había terminado con ella y creo que todavía la veía. El hecho es que nos veíamos en París todo ese grupo de gente, que después me fui a La Habana, me casé y me descasé enseguida. Él estuvo con Maggie muchos años.

EMS: Pero entonces, ¿̨por qué se casó usted? Es decir ¿por qué se casaron, si aparentemente la relación no era buena?

EVA: No era buena la relación, pero yo le había prometido a papá que me casaría con él, porque papá sabía que yo salía mucho con él. Papá me decía: tienes que casarte por tu reputación.

Casada y divorciada en el arco de pocas semanas, Eva contrae, entonces, nuevo matrimonio con quien la había pintado varias veces, vestida y desnuda, durante aquel mes 
de fulmínea y delirante pasión. Así lo confirma un testimonio de Félix Ayón sobre las fiestas en El Hurón Azul durante el período del regreso de Carpentier en 1939:

A veces iba Alejo Carpentier con Eva Fréjaville. Me acuerdo que también iba Juan Chabás; Martínez Pedro y Juan David iban algunas veces, así como Juan Marinello, el poeta Pita Rodríguez, etcétera, etcétera. En realidad, tampoco había extranjero -intelectual, artista o diplomático- que, pasando por La Habana, no fuera de visita a El Hurón Azul. Las tardes transcurrían así, muy divertidas. Se escuchaba buena música. La gente que lo visitaba era siempre de gran calidad, de gustos distintos, distintas concepciones morales... Recuerdo que tiempo después, sobre la chimenea que hizo construir en El Hurón, pintó un paisaje con muchas mujeres bañándose en un río. Todas estaban inspiradas en Eva Fréjaville, quien se convirtió en su segunda esposa. También pintó a Eva en la puerta del baño, desnuda, una de sus mejores pinturas (Sánchez, 2005, p. 124).

Ya casados Carlos y Eva, uno de los amigos que siguen frecuentando El Hurón Azul es el abogado Agustín Guerra y de la Piedra, quien solía llegar «jinete sobre un caballo blanco, hermoso y trotador». Escribía versos:

Todo es azul en el Hurón Azul, el hurón, la risa de Eva, el cavilar de Carlos, los ojos de las plantas...

Y por más que veo oro en la copa de ron Matusalem, cuando bebo, bebo azul.

En su fase inicial el matrimonio funciona:

Durante estos años Eva Fréjaville ha sido indiscutible musa de carne y hueso en su pintura. Parejamente fue un buen estímulo intelectual a la hora de escribir novelas y cuentos de ambiente campesino. Muchas de las figuras que aparecen en sus cuadros del período 1940-1944, sin ser retratos, tienen el aire espléndido, de maíz en plena sazón estallante, de Eva. La pinta con obsesión reiterativa sobre una de las paredes de la sala y hasta sobre el zinc de la puerta del baño, en El Hurón Azul. Le dedica, con frases de cálido cariño, los principales textos que escribe, sus novelas La feria de Guaicanama y La vuelta de Chencho. Ya lo había hecho con Tilin García (Sánchez, 2005, p. 165).

La novela Tilín García, escrita por Enríquez y publicada por Manolo Altolaguirre en sus Ediciones La Verónica (1939), trae esta dedicatoria: «À Eva Fréjaville, la brave mâ̂tresse de L'Huron Bleu». Enríquez escribió otras dos novelas, La feria de Guaicanama y La vuelta de Chencho, publicadas después de su muerte. Estas ediciones, a cargo del Ministerio de Educación de Cuba, datan de 1960. La feria de Guaicanama se supone escrita en 1940 y está dedicada también a Eva Fréjaville, «dont l'amour courageux m'a fait galoper jusq'aux aubes de Guaicanama».

Sin embargo, «aquella relación que el temperamento liberado de Eva tornaba a veces compleja y eruptiva, se fue transformando en una especie de posesión anormal y delirante por parte de Carlos» (Sánchez, 2005, p. 165). La mencionada nota anónima trae una manifestación del proceso: «Meses después, en otra de las orgías de la finquita de Párraga, el escritor Enrique Labrador Ruiz, eufórico de humo y alcohol, se propasó con la francesa y la reacción de Enríquez fue virulenta, expulsándolo a golpes de la tertulia alucinante». En otra nota, firmada, Graziella Pogolotti precisa: «Carlos era muy machista. Durante la primera etapa de su relación con Eva Fréjaville, prácticamente la mantenía presa en el Hurón Azul. Poco a poco ella sintió la necesidad de poner fin a ese encierro y salir a la ciudad, donde impartía clases de francés en la Hispanoamericana de Cultura. La tenía siempre bajo control. Por lo menos se había construido un personaje así. En realidad no era tan fiero».

La misma Pogolotti ofrece importante información de primera mano en un ulterior excelente artículo (2006):

Eva empezaba a mostrar señales de cansancio. Se quejaba con amigos. La fortuna heredada por el pintor se consumía rápidamente mientras se acrecentaba su dependencia alcohólica. En un intento de reconciliación, viajaron a México, donde ella conservaba un vínculo muy antiguo con Diego Rivera, según Carlos, padre de su mujer. Entre ambos había, en efecto, ciertos rasgos de parentesco. Íntimo amigo de la familia el muralista le hizo un precioso retrato a la pequeña, situada al centro de una composición dominada por una sutil gama de sepias y marrones. Atenuados el grueso de los labios y el volumen de los globos oculares, el rostro de la niña guardaba lejano parentesco con los rasgos de su madre Zizou.

Durante ese viaje de 1944 a México «la singular pareja formada por Carlos Enríquez,

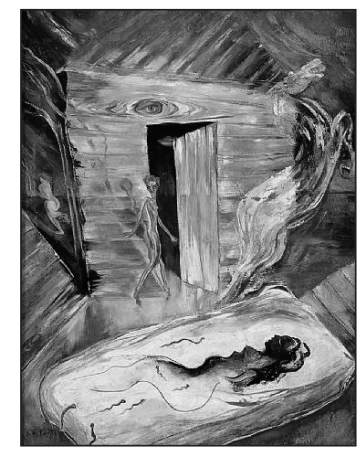

Eva Fréjaville II, de Carlos Enríquez.

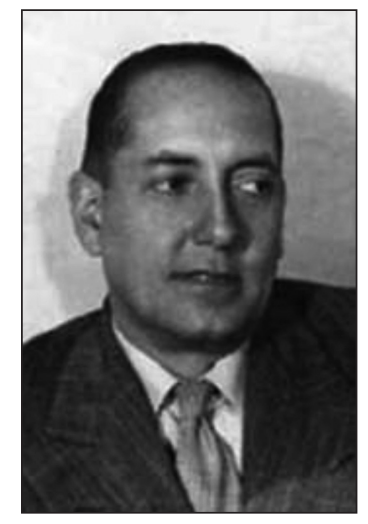

Alejo Carpentier años '30.

Eva: la musa secreta de neruda en «Las furias y las penas» HERNÁN LOYOLA 
criollo, delgado, nervioso, y por Eva Fréjaville, la joven francesa, inteligente y hermosa, conquistó las simpatías de todo el mundo» (Sánchez, 2005, p. 147). Enríquez escribe a su

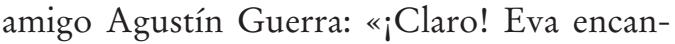
tada, pues ha encontrado amigos de su padre [¿alude a Diego Rivera o a Gustave Fréjaville?] y hasta camaradas de letras (amigos de la avant-guerre). La prensa nos ha acogido bondadosamente, escribiendo encomiásticos artículos sobre nosotros» (Sánchez, 2005, p. 150). Y en otra carta: «Hemos recibido dos remesas del Marcel Proust, las cuales creo suficientes para saciar la curiosidad del revuelo proustiano despertado por la Fréjaville» (Sánchez, 2005, p. 154).

Pero al regresar a La Habana, la situación se precipitó. «La relación de Eva con Carlos se hizo siempre más tormentosa, el narcisismo del pintor ahogaba el albedrío de Eva. De ese conflicto continuo sacó ventaja Cynthia Carleton, una lesbiana inglesa que asistía a las reuniones del Hurón acompañada por el estilista Renée. Aparentemente, Carlos disfrutaba de los lances eróticos entre Eva y Cynthia sin imaginarse que más allá de la pasión, entre las dos mujeres crecía una íntima ternura. La fuga de Eva con Cynthia fulminó al artista, quien no halló consuelo ni siquiera con Germaine y su hermana, dos lindas mulatas haitianas provenientes de una familia adinerada, que se enamoraron al unísono de la bohemia y la fogosidad de Carlos» (nota anónima).

Un día de 1945, con letra temblorosa, él comunicó a su amigo Agustín Guerra: «Anoche nos separamos Eva y yo».

Este manuscrito, con letra temblorosa, se conserva en el archivo municipal de El Hurón Azul. Poco después de la separación de Eva y Carlos, este cubrió con pintura el retrato de ella que había realizado sobre la puerta del baño. El arquitecto Jorge Fernández de Castro le pidió la puerta a fin de salvar la obra de arte, pensando en una posterior restauración. «Bueno, cuando consigas otra puerta te regalo la que tiene a Eva pintada. A fin de cuentas la pinté donde merece estar...», dijo Carlos recuperando su humor. El retrato de Eva desnuda fue finalmente restaurado y se conserva en el Museo Nacional de Bellas Artes (Sánchez, 2005, p. 165, nota 90).

Tras divorciarse de Enríquez, algún tiempo después Eva contrae un nuevo matrimonio con el médico comunista Enrique Collado. En esta fase de su vida Eva retoma sus in- quietudes literarias que en 1942, por ejemplo, se habían manifestado a través del volumen Marcel Proust desde el trópico, también publicado por las Ediciones La Verónica de Manolo Altolaguirre. Hay un testimonio del escritor cubano Antón Arrufat sobre las reuniones literarias a que convocaba Eva durante los años cincuenta:

En ese período frecuentábamos las tertulias habaneras, otra manifestación de la vida cultural de la ciudad. Recuerdo que con frecuencia [Virgilio] Piñera asistía a la de Eva Fréjaville, que recibía en su casa del Vedado. Mujer culta, un poco cursi, de risa estentórea, en otra época fue mujer del pintor y novelista Carlos Enríquez. Algunos otros escritores íbamos también a la casa de «madame Evá», como burlonamente la llamaba Virgilio. Había que oírlo cuando salía de aquellas tertulias, a las que en el fondo despreciaba. Mas en él siempre hubo esa especie de dicotomía: despreciar algo y, a la vez, sentirse atraído por ese algo. Sin duda aquellas visitas y relaciones constituían para él un alimento contradictorio, una experiencia de la que no quería privarse.

Pero entonces llega Fidel con su revolución de 1959 y Eva comienza a no sentirse $\tan$ a gusto en Cuba. Discute con su marido comunista y abandona el país en 1961 rumbo a Francia y luego a Estados Unidos, donde se radicará hasta su muerte en 1998 a los 85 años. Como ya sabemos, Enrico Mario Santí la había entrevistado en 1992:

Hará unos doce años, en una de mis primeras estancias en las cercanías de Los Angeles, leí en Linden Lane Magazine un notable artículo sobre el genial pintor cubano Carlos Enríquez. Me llamó la atención que se identificara a su autora, Eva Fréjaville, como una profesora que residía en Riverside, California, muy cerca de mi casa. En seguida reconocí el nombre como el de la primera esposa de Carpentier, a quien Madame Fréjaville había dejado, como parte de una legendaria aventura de los años cuarenta en Cuba, por aquel pintor surrealista, con quien por cierto se casó después. Las malas (o buenas) lenguas hasta decían que el infame personaje de Mouche, en Los pasos perdidos, se inspiraba en ella. Picado por mi curiosidad, pude obtener su número de teléfono. Una señora amable, y de predecible acento galo, me contestó, y $[\ldots]$ me dio cita en su apartamento al día siguiente.

Eva Fréjaville resultó, como se dice en USA, a character. Rozaba ya los ochenta años, era de estatura pequeña y bastante corpulenta, todo lo cual no le 
impidió recibirme elegante, tal vez un tanto subida de color para su edad, ella misma muy pintada. Sobre todo, lúcida, vivaz, simpática. Pero había sido bella, como anuncia su nombre y evidencian los retratos que llegó a hacerle Enríquez. Entre bombones y Grand Marnier, pasiones suyas, abordamos su niñez y adolescencia en París, hija de Gustave Fréjaville, famoso crítico de teatro parisino; su intenso círculo de amistades, que entonces incluía al poeta Robert Desnos y a Youki, su célebre acompañante; y, desde luego, su vida con Alejo Carpentier.

En el texto de esa entrevista, que Santí dará a conocer en 2004 (y en Linden Lane Magazine, 2005) con motivo del centenario de Carpentier, Eva no menciona a Neruda. Personalmente, sin embargo, no tengo ninguna duda de que Eva es «la mujer de Carpentier» aludida por Pablo. A través de citas $\mathrm{y}$ testimonios -que en general me parecen atendibles- sólo he intentado reconstruir un retrato de Eva que, creo, explica la tensión del poema aquí enfocado.

Pero la joven francesa, «posible hija natural de Diego Rivera» según Luisa Campuzano (2006) y otros, habría sido también el referente real-«como sabe todo aquel que se mueve en el medio cultural cubano»- del personaje Mouche de Los pasos perdidos (1953), a través del cual Carpentier canaliza «la venganza literaria del amante abandonado y escritor». Lo mismo afirma Leonardo Acosta: «Any literary critic or writer who lived in Havana would identify Mouche with an ex-wife of Alejo, the French Eva Fréjaville» (2008, p. 132).

Siempre según Campuzano, el nombre Mouche proviene de una fábula de La Fontaine, «Le Coche et la Mouche» (VII, 8), pero el personaje se nutre además de algún episodio de Nadja de Breton (según Maryse Renaud), de la Albertine de Proust (según Benito Pelegrín) y hasta de «entremezcladas lecturas que la hacen tan bovariana» (según Roberto González Echevarría). Concluye Campuzano: «Y después de haber reinado y seguir reinando, gracias al amor y la inquina de Carlos Enríquez, en los museos, en libros de arte, en posters, postales y catálogos, Eva Fréjaville vuelve ahora a la literatura como protagonista de Juego interrumpido, novela del cubano Lisandro Otero, en curso de redacción, y uno de cuyos capítulos apareció hace meses en $\mathrm{La}$ Gaceta de Cuba» (2002, pp. 69).

\section{Primer acto: Madrid 1934}

Muy poca información he logrado encontrar sobre los viajes de Alejo Carpentier desde París a España en 1934. Por supuesto, vino a Madrid cuando en 1933 apareció su primera novela ¡Écue-Yamba-O! Con

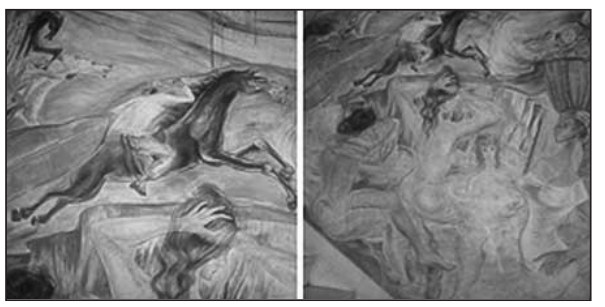
Eva Fréjaville III, Fuente. Revista cubana La Jiribilla. las mil pesetas que le pagaron Luis Araquistain y Julio Álvarez del Vayo por esa publicación, Carpentier dio un banquete a sus amigos españoles. "El viaje a Madrid fue inolvidable para Carpentier. Allí se encontró con un amigo de los días de Montparnasse: John Dos Passos. Sobre todo, allí alternó con los más grandes poetas de su generación: con Alberti y Altolaguirre, con Federico García Lorca, José Bergamín, Antonio Marichalar. Al año siguiente [1934] también viajó a España, en diciembre, trasladándose a la capital por invitación del propio García Lorca, para el estreno de Yerma en el Teatro Español» (Vásquez, 1980, p. 182). Sin embargo, no hay mención de Carpentier en los libros de Gibson $(1987,2009)$ sobre Federico, ni en Sáenz de la Calzada (1976) ni en los diarios de Morla Lynch (2008), donde la ausencia me parece particularmente digna de notar.

A falta de otros antecedentes, presumo entonces que Pablo y Alejo se encuentran por primera vez en diciembre de 1934, durante la permanencia de Carpentier en Madrid con ocasión del estreno de Yerma. A Neruda por cierto no podía faltarle interés por conocer al director de la efímera revista Imán y fallido editor de la primera Residencia en París 1931 (al respecto, remito a Loyola, 2006, pp. 503-505, donde confirmo con otros datos la tendencia de Carpentier a una cierta mitomanía personal, o sea a mentir como decía Eva). Presumo también que en aquel diciembre de 1934, durante esos encuentros, brotó la chispa de atracción recíproca entre Pablo y Eva, la seductora y vivaz muchacha francesa que acompañaba al escritor cubano; y que ella se las ingenió para vivir con el poeta chileno un fugaz pero intenso flirt clandestino antes de regresar a París.

La asociación mnemónica de ese flirt con el estreno de Yerma habría determinado, a mi entender, que cinco años después Neruda fechara en 1934 la escritura de «Las furias y las penas». Pero las características del texto hacen que esa fecha a mí no parezca posible. Creo,

Eva: la musa secreta de neruda en «Las furias y las penas» HERNÁN LOYOLA 
en cambio, que el poema quizás fue iniciado al cierre de 1934, pero que su elaboración más o menos definitiva (porque conjeturo además algunos retoques menores poco antes de las publicaciones del texto en 1939) tendrá lugar durante el verano y comienzos del otoño de 1935, tras el regreso de Neruda desde París, a donde había viajado, en junio, como delegado chileno al congreso internacional de escritores antifascistas. Y donde con seguridad había reencontrado a Eva Fréjaville en la residencia de Carpentier (y fuera de ella).

\section{Segundo acto: París 1935}

No sólo el Congreso de los escritores antifascistas, entonces: también Eros galvaniza a Pablo en aquel junio de 1935. Hay una cartatestimonio de Arturo Serrano Plaja a Manuel Aznar Soler (1987, II, pp. 687-688) que certifica el «plan de austeridad» acordado con Neruda y González Tuñón para prolongar la estadía en París cuanto fuese posible, reduciendo al mínimo los gastos pero sin adoptar la extrema dieta de patatas que por muchos años practicó Vallejo (y que en 1938 determinará -según Robertson 2009- su precoz muerte, sólo en apariencia misteriosa). Serrano Plaja recuerda que una mañana sorprendió a sus compañeros Pablo y Raúl agregando una golosina al café crême de reglamento, por lo cual les enderezó un dolido reproche. Neruda entonces, sonriendo, le respondió en versículos rimados: «el delegado de España / no come pero se baña", haciéndole saber así que la ducha fría que recién había tomado Serrano Plaja, causa de su retraso en bajar al café Dôme, pasaba también a la cuenta del hotel como gasto extra.

Y aquí el español agrega: "Alguna noche había un poco más de fiesta, gracias, creo, a Alejo Carpentier, a quien conocí entonces y que trabajaba en alguna casa de música y tenía algo más de dinero, y también a Robert Desnos, que nos invitó alguna vez a su casa, en la que tampoco había muchos lujos». Precioso testimonio que de hecho certifica el reencuentro de Neruda y Carpentier e, indirectamente, el de Pablo y Eva Fréjaville. Lo confirma Carmen Vásquez, que por amistad personal con Carpentier tuvo acceso a información privilegiada: a su amigo el poeta Robert Desnos. Asistía además, como espectador, al Congreso, interesándose, quizás principalmente a causa de su amistad con Desnos, en la polémica con los surrealistas. Neruda, recién ingresado en el ambiente, no podía sino hacer lo mismo.

Las conversaciones se prolongaron fuera del ámbito del Congreso, por el Barrio Latino, con Carpentier en la Place Dauphine, donde éste vivía, y hasta en la rue Mazarine, en cuyo segundo piso tenía Desnos su acogedor apartamento. Allí llegó Neruda una noche, poco antes de su regreso a Madrid. Se habló de España -Desnos ya la conocía y pensaba volver a visitarla dentro de poco-, de política, de literatura y del surrealismo. La polémica candente del Congreso, la intervención de Breton a través de Paul Éluard, las discusiones de Aragon y las expulsiones frecuentes del grupo de los surrealistas eran temas conocidos por Desnos, quien había sido uno de los más notorios surrealistas expulsados. Y sabido era que, cinco años después de su ruptura con Breton, la amargura no había podido atenuarse. Neruda, por su parte, se llevaría consigo estos recuerdos y, en particular, el de la velada en la rue Mazarine (Vásquez, 1981, pp. 55-56).

A partir de estos datos conjeturo que «Las furias y las penas» fue completado o reelaborado por Neruda al regresar a Madrid en los primeros días de julio (hay carta suya a Desnos allí fechada el 7 de ese mes). $O$, con más probabilidad, algún tiempo después, según lo sugieren dos datos: (1) dentro del poema la referencia inicial al «verano de tigres» cambiará, hacia el final, a «un otoño / negro ha llegado»; (2) Carpentier, seguramente acompañado por Eva, en septiembre estará de nuevo en $\mathrm{Ma}$ drid, desde donde escribe el día 11 a Desnos solicitándole en nombre suyo $y$ de Neruda una colaboración para su inminente revista Caballo Verde (texto en Vásquez, 1981, p. 57). Al pie de esta carta Neruda manuscribió personales y cálidos saludos a Desnos y a Youki, su mujer.

Ahora bien, mi hipótesis es que «Las furias y las penas» documenta en clave poética que el reencuentro con Eva en París (y en Madrid más tarde) no respondió del todo a las expectativas de Pablo. Si Eva tenía 85 años cuando murió en 1998 (como asegura Enrico Mario Santí), en 1935 era una jovencita de sólo 21 ó 22 años que había crecido respirando desde muy niña la atmósfera de trasgresión proclamada y ostentada por los surrealistas amigos de su padre, y que además era inquieta de carácter ella misma, de temperamento vivaz y muy consciente de sus 
eróticos atractivos. Lo confirma el retrato que, a sus casi 80 años, de ella trazó Santí al entrevistarla en Riverside. Por lo cual es muy probable que la jeune fille en fleur de 1935 quisiera, aparte Carpentier, ensayar el amor o probar con otros hombres su capacidad de seducción, pero sin comprometerse demasiado con ninguno. $\mathrm{Ni}$ siquiera con el interesante poeta chileno que había conocido en Madrid a fines de 1934.

Las ardientes promesas del diciembre madrileño, y las coqueterías que presumiblemente siguieron por correspondencia durante los meses sucesivos, en París muestran a Pablo su verdadero alcance. Dado el fuerte tono erótico de «Las furias y las penas», de seguro nuestro poeta había escrito muchos apasionados mensajes, o telefoneado más de una vez desde la sede consular, a su nueva y excitante amiga parisiense. Imagino cartas como las que por años había escrito a Albertina Azócar, si bien más audaces ahora. El poema sugiere un cierto tiempo de relación erótica (que habiendo sido breve en Madrid se habría prolongado por vía epistolar) y sugiere también desilusión y cólera porque Eva no muestra hacia él, en París, ese interés particular que espera o sueña desde diciembre. Peor todavía: aunque al parecer hubo varios encuentros íntimos, Neruda se entera -quizás por ella misma- de que la muchacha no desdeña citas similares con otros escritores o artistas del ambiente surrealista (el poema menciona incluso a un cierto «peruano rojo» que podría ser Vallejo -un indicio más que conecta al poema con París). Otras veces Eva lo deja plantado o no accede a sus requerimientos por temor a Carpentier y a su propio padre (atento a la reputación de su hija, según recordará ella misma en su entrevista con Santí), En suma, la chica es coqueta y desprejuiciada, pero, al mismo tiempo, más convencional de lo que parece.

\section{La pasión defraudada}

En el fondo del pecho estamos juntos, en el cañaveral del pecho recorremos un verano de tigres, al acecho de un metro de piel fría, al acecho de un ramo de inaccesible cutis, con la boca olfateando sudor y venas verdes

nos encontramos en la húmeda sombra que deja caer besos.

El punto de arranque del poema es la imagen de un encuentro erótico («estamos juntos...nos encontramos») continuativo o reiterado («recorremos un verano») y marcado por signos de vehemencia carnal y ardor instintivo, zoomorfizados para sugerir intensidad (tigres... al acecho... olfateando sudor $\mathrm{y}$ venas verdes...). En las secuencias sucesivas el Sujeto enunciador descompone la dualidad (estamos, recorremos, nos encontramos) y dentro del mismo marco convierte al otro miembro en destinataria del discurso:

Tú mi enemiga de tanto sueño roto de la misma manera que erizadas plantas de vidrio, lo mismo que campanas deshechas de manera amenazante, tanto como disparos de hiedra negra en medio del perfume, enemiga de grandes caderas que mi pelo han tocado con un ronco rocío...

no obstante el mudo frío de los dientes y el odio de los ojos, y la batalla de agonizantes bestias que cuidan el olvido, en algún sitio del verano estamos juntos acechando con labios que la sed ha invadido.

Estos versos trazan la contradicción de base: atracción / rechazo (o fascinación / odio), cuya dinámica se resuelve en «frustración y resentimiento» para el Sujeto. Así, el tema fundador que las primeras estrofas del texto exponen y que las siguientes varían y detallan es la disolución de un sueño, de una esperanza, lo cual atraerá, en la zona final del poema, la evocación de un antiguo episodio erótico (que nos dará la verdadera clave de lectura). Las fórmulas «erizadas plantas de vidrio, campanas deshechas y disparos de hiedra negra en medio del perfume» convergen sobre la degradación y ruina de instancias promisorias (plantas, campanas, perfume). La figura femenina -destinataria del discurso poético-viene señalada como causante de estas «furias y penas» del Sujeto, que desembocan en una conclusión de nivel más general, como queriendo justificar el poema.

Porque a los 18 versos citados siguen otros, hasta el 107, que en apariencia son una lista de acusaciones, una especie de cabier de doléances, pero a través del cual el Sujeto elabora un apasionado retrato de su amante innombrable. A quien sólo llama «Enemiga», así como años antes llamó «Maligna» a su amada Josie Bliss en «Tango del viudo»: sólo que entonces había amor de por medio (dato significativo según veremos). En cambio esta larga letanía del despechado de París recuerda más bien la monocorde pasión erótica del centenar de cartas a Albertina durante los
Eva: la musa secreta de neruda en «Las furias y las penas» HERNÁN LOYOLA 
años '20. En el caso actual, la secuencia sucesiva nos entrega el retrato de una mujer tanto deseada cuanto reticente hacia nuestro poeta (porque activa «predatora» de más hombres).

Cuando en las reuniones

el azar, la ceniza, las bebidas,

el aire interrumpido,

pero ahí están tus ojos oliendo a cacería,

a rayo verde que agujerea pechos,

tus dientes... tus piernas...

y tus tetas de nácar y tus pies de amapola...

aun más, aun más,

aun detrás de los párpados, aun detrás del cielo,

aun detrás de los trajes y los viajes, en las calles donde

adivinas los cuerpos...

[la gente orina,

Adivinas los cuerpos!

Como un insecto herido de mandatos

adivinas el centro de la sangre...

Hueles lo húmedo en medio de la noche?...

Oyes caer la ropa, las llaves, las monedas

en las espesas casas donde llegas desnuda?

Mi odio es una sola mano que te indica

el callado camino, las sábanas en que alguien ha dormido

con sobresalto: llegas

y ruedas por el suelo manejada y mordida,

y el viejo olor del semen como una enredadera

de cenicienta harina se desliza a tu boca.

Las «reuniones» aludidas al comienzo de estos fragmentos (elegidos entre los versos 2562) podrían evocar una tertulia en Cervecería Correos a fines de 1934, en los días del estreno de Yerma, entre los amigos que rodean al estelar Federico; o bien una conversación entre participantes al Congreso de París (junio 1935) que se conceden una pausa para descansar, fumar y beber en algún café cercano al Palais de la Mutualité. Este tipo de lenguaje y de ambientación urbana son habituales en los poemas de la segunda Residencia. Podemos imaginar a Eva junto a Carpentier, quien asombra con su excepcional cultura literaria y musical a los interlocutores próximos, mientras desde otro ángulo Neruda observa a Eva que intercambia miradas con él... y con otros miembros del grupo («tus ojos oliendo a cacería»). Poco a poco los versos abandonan el espacio cerrado y concreto de la cervecería o del café y despliegan por siniestras calles y «agrias iglesias a medio destruir» el instintivo talento erótico y la destreza sensorial de la muchacha («Adivinas los cuerpos! / Como un insecto berido de mandatos / adivinas... / Hueles lo húmedo...? / Oyes caer la ropa...?»). Versos marcados por el intento de mostrarla bajo una luz ética negativa o degradada («llegas desnuda...ruedas por el suelo manejada y mordida... y el viejo olor del semen... se desliza a tu boca»). Pero la vehemencia y la magnífica precisión erótica del lenguaje, y más aún el resultante odio que declara el verso 57, en conjunto manifiestan, por el contrario, el fracaso del intento explícito y el triunfo poético -al trasluz- de una pasión auténtica, si bien defraudada.

\section{Rosa-Josie-Eva}

La siguiente secuencia (versos 63-107) abandona el tono de reproche para asumir -ya más tranquilo y conversando con Eva mismala inesperada desilusión. Tras un metralleo de imágenes que en conjunto resumen lo vivido con ella («Ay leves copas y pestañas, / aire que inunda un entreabierto río / como una sola paloma de colérico cauce... / ay substancias, sabores, párpados... / ay graves, serios pechos... / ay grandes muslos... / y talones y sombras de pies... / respiraciones... / y duras olas que suben la piel hacia la muerte / llenas de celestiales harinas empapadas»), el poeta pregunta y busca aún saber si en verdad ella no ha compartido ni comprendido el valor existencial que para él tuvo la común experiencia erótica:

Entonces, este río

va entre nosotros, y por una ribera

vas tú mordiendo bocas?

Entonces es que estoy verdaderamente, verdaderamente [lejos

y un río de agua ardiendo pasa en lo oscuro?

Aceptando la propia ceguera, o sea la propia equivocación, Pablo reitera a Eva que su odio resignado la perseguirá «para que nunca, nunca / hables... para que nunca, nunca / salga una golondrina del nido de la lengua / y para que las ortigas destruyan tu garganta / y un viento de buque áspero te habite». A esta maldición premonitoria siguen preguntas que ya no son solamente reproches a su amante sino un modo aún apasionado de sacudirla, de hacerla ver qué está haciendo ella con su propia vida:

En dónde te desvistes?

En un ferrocarril, junto a un peruano rojo 
o con un segador, entre terrones, a la violenta luz del trigo?

O corres con ciertos abogados de mirada terrible

largamente desnuda, a la orilla del agua de la noche?

$\mathrm{El}$ «peruano rojo» podría no aludir a $\mathrm{Va}$ llejo sino más bien, enmascarada u oblicuamente, al «cubano rojo» que sería Carpentier, «junto a» quien ella estaría malgastando su vida (lo que en efecto, como ya anticipé, Eva Fréjaville verificará rápidamente en La Habana, 1939). De ahí que dichas preguntas precedan a una especie de advertencia acerca de lo que pierde: «Miras: no ves la luna ni el jacinto / ni la oscuridad goteada de humedades, / ni el tren de cieno, ni el marfil partido: / ves [sólo] cinturas delgadas como oxígeno, / pechos que aguardan acumulando peso / e idéntica al zafiro de lunar avaricia / palpitas desde el dulce ombligo hasta las rosas».

Estos dos últimos versos (106-107) me parecen significar, sin perjuicio de la anterior advertencia dictada por la pasión despechada, una especie de final -y también resignadoreconocimiento de la fresca y juvenil vitalidad que subyace al promiscuo erotismo de la muchacha. Reconocimiento dictado, en cambio, por los progresos que ha hecho Neruda en su ya larga tentativa de esclarecer y dar un estatuto (en vida y en poesía) a su propia sexualidad. De tales progresos han dado cuenta en clave poética los últimos textos de Residencia en la tierra, y en particular la colocación del poema «Josie Bliss» al cierre de la obra.

Sólo así se explica, a mi juicio, el imprevisible giro que toma la secuencia sucesiva (versos 108-153) de "Las furias y las penas». Habiendo atravesado la prueba de «las furias», vale decir los efectos inmediatos y traumáticos de su historia con la muchacha, ahora el poeta logra ir más allá del puro desahogo visceral y descender a una zona más profunda de su íntima experiencia, a un nivel de conquistada sabiduría o de mayor madurez. Es un territorio de «penas» muy hondas éste al que «Pablo» ha bajado, y ya no se trata de las penas de amor-deseo que le deparan en París los desvíos de la excitante «Eva». Desvíos que de pronto el poeta declara -con su más personal lenguaje-comprender y aceptar:

Por qué sí? Por qué no? Los días descubiertos aportan arena roja sin cesar destrozada a las hélices puras que inauguran el día, y pasa un mes con corteza de tortuga, pasa un estéril día, pasa un buey, un difunto, una mujer llamada Rosalía, y no queda en la boca sino un sabor de pelo y de dorada lengua que con sed se alimenta.

Nada sino esa pulpa de los seres, nada sino esa copa de raíces.

Aunque sin espacio para explicarme en detalle, leo en este golpe de timón el injerto de una reflexión que asume la forma de una «secuencia-sumario» en la que «Eva» inicialmente desaparece (sea como personaje que como destinataria del discurso poético) para dar lugar a un resumen, o mejor a un condensado y doble itinerario: por un lado, de la intensa y atormentada trayectoria sexual de «Pablo» (hasta llegar a «Eva»); por otro, de la paralela escansión de la búsqueda de su significado y resolución (en la vida y para la escritura). Los versos citados hablan de un originario «desarrollo temporal» marcado por descubrimientos, inauguraciones, transcursos de días y meses, eventos y animales y personas, vale decir, por sucesivas experiencias de infancia y adolescencia -por ello originarias, inaugurales, descubridoras- avanzando en el tiempo hacia una figura central, nuclear, hacia «una mujer llamada Rosalía», que a mi entender es una cifrada alusión a Albertina Rosa Azócar (una mujer también cifrada Rosaura en Memorial de Isla Negra, 1964).

Albertina Rosa había sido para Pablo en los años 20, antes del viaje a Oriente, la encarnación máxima del fuego sexual y del placer erótico al estado puro. Durante varios años Pablo escribió en vano innumerables cartas, porfió, viajó, amenazó, hizo de todo para acostarse de nuevo con quien había sido su amante en Santiago. Incluso le ofreció matrimonio desde Wellawatta. Hasta la aparición de Josie Bliss en Rangoon, ninguna otra mujer suscitó en el poeta una pasión carnal tan devoradora. Pues bien, en este citado pasaje de «Las furias y las penas» Neruda admite la importancia instintiva de aquella experiencia, y a la vez su inanidad respecto a la perspectiva profunda que soñaba. Admite, en suma, su autoengaño: "y no queda en la boca sino un sabor de pelo / y de dorada lengua...». Pero el pasaje siguiente declara otra experiencia que fue en cambio verdadera:

Yo persigo como en un túnel roto, en otro extremo, carne y besos que debo olvidar injustamente...
Eva: la musa secreta de neruda en «Las furias y las penas" HERNÁN LOYOLA 
La fórmula «en otro extremo» tiene alcance geográfico (al otro extremo del mundo) y al mismo tiempo existencial (una validez extrema, a diferencia de la experiencia antes aludida). La carne y los besos que el poeta debe "olvidar injustamente» son los de Josie Bliss. Ella había encarnado de veras el sueño antes ilusoriamente perseguido a través de Albertina Rosa (erotismo con amor), pero a la vez había encarnado su imposibilidad. A la historia de Pablo y Josie dediqué todo el capítulo VI y parte del VII en el primer volumen de mi biografía del poeta (Loyola, 2006). Los capítulos II al IV del segundo volumen (en preparación) narrarán el duro proceso de ese «olvidar injustamente» que culminó con la paradoja, aparente, de asignar el nombre de aquella mujer al poema final de Residencia en la tierra: «Josie Bliss». Al respecto, remito por ahora a la "Introducción» y notas a mi edición crítica de Residencia (Loyola, 1987).

... cuando

todo me dice que un día ha terminado, tú y yo

hemos estado juntos derribando cuerpos,

construyendo una casa que no dura ni muere...

tú y yo hemos hecho temblar otra vez las luces verdes y hemos solicitado de nuevo las grandes cenizas.

Recuerdo sólo un día

que tal vez nunca me fue destinado, era un día incesante,

sin orígenes, Jueves.

Yo era un hombre transportado al acaso

con una mujer hallada vagamente, nos desnudamos

como para morir o nadar o envejecer

y nos metimos uno dentro del otro,

ella rodeándome como un agujero,

yo quebrantándola como quien

golpea una campana...

«Eva» pudo haber sido la reaparición de Josie Bliss, una segunda oportunidad para el amor total, l'amour fou de Neruda, por eso su desvío duele tanto, y por eso el desengaño atrae al texto un paréntesis («Recuerdo sólo un día...»: versos 133-153) que de otro modo resulta incomprensible: es la evocación de un día vivido por Neruda años atrás, en 1927, el día del desembarco en Rangoon tras navegar varios meses por dos o tres océanos. Aquel día de angustia por un destino que aparecía incierto y duro, el poeta había salido a caminar y junto a los muelles del puerto había encontrado a una joven birmana solitaria, sentada frente al mar, y ambos, sin comunicación verbal posible, se reconocieron en la soledad compartida y sin palabras se apartaron hacia algún lugar donde hicieron el amor con desesperación, hasta el agotamiento. Este episodio, fugaz y sin continuación, dejó sin embargo una huella tan profunda en Neruda que más de 30 años después, en 1964, lo revivirá con extraña intensidad en el poema «Rangoon 1927» de Memorial de Isla Negra [para un análisis e interpretación más detallados de este cruce de textos, remito a Loyola, 2006, pp. 293-297]. En vez de Josie Bliss, Eva repropone en el texto de 1935 la figura de aquella anónima co-protagonista de un inolvidable «cuento de puertos», cuya evocación es sin embargo la clave de «Las furias y las penas». Lo certifican -y explican- los versos inmediatamente sucesivos al paréntesis:

\section{Enemiga, enemiga, es posible que el amor haya caído al polvo y no haya sino carne y huesos velozmente adorados mientras el fuego se consume \\ y los caballos vestidos de rojo galopan al infierno?}

Fue sorprendente para mí verificar, a la luz de estos versos, cuánta ilusión y cuántas esperanzas había puesto Neruda en su relación con «Eva», esa mujer a quien nunca mencionó en sus escritos. Una relación que fue muy importante y significativa, de la cual, sin embargo, nada sabríamos quizás, ni siquiera imaginaríamos, si yo no hubiera interrogado a Neruda sobre la identidad real -extratextual- de la destinataria interna del discurso de «Las furias y las penas». Sabemos ya cuánto son elocuentes los silencios (lo no dicho) en la vida-escritura de Neruda (ejemplo extremo: Malva Marina). Aquí el silencio equivale a ocultar una íntima y secreta derrota, de la cual «Las furias y las penas» es el solo cifrado, críptico testimonio. Una vez más, al parecer, Neruda había soñado refundar su poesía sobre la convivencia de una pasión total (erotismo y amor, l'amour fou) con una vocación "profética» en vías de redefinición. Tentativa quizás más viable -en apariencia- que aquélla con la birmana Josie, suponiendo una mayor afinidad cultural con la francesa «Eva».

Pero si más allá de los deseos de Pablo, y según lo que el texto sugiere, hubo un real encuentro entre erotismo y enamoramiento (sexo con amor, diríamos hoy), esa conver-
"Las furias y las penas"
LERNAN

HERNÁN LOYOLA 
gencia fue de corta duración. Importa subrayar que en este caso, como en el de Josie Bliss, es precisamente el alto nivel de la gratificación erótica lo que torna inaceptable la unilateralidad, la ausencia del otro polo dialéctico: ausencia de amor en la relación con Eva, ausencia de sintonía cultural en la relación con Josie. Porque Neruda vivió con naturalidad y alegremente, sin problemas ni secuelas dignas de notar, incontables amoríos (sexo sin amor). Pero ni a Josie ni a «Eva» pudo reducirlas al nivel de simples «amoríos». Justo porque le gustaban extremadamente, porque se enamoró de ellas con arrebato, sólo pudo asignarles en su vida un rol que en ambos casos devino imposible por motivos diferentes. Un rol conexo, ya lo sabemos, al no negociable desarrollo de la vocación "profética» de su poesía.

Yo quiero para mí la avena y el relámpago a fondo de epidermis, y el devorante pétalo desarrollado en furia, y el corazón labial del cerezo de junio, y el reposo de lentas barrigas que arden sin dirección, pero me falta un suelo de cal con lágrimas y una ventana donde esperar espumas.

En estos versos Neruda denuncia a modo suyo la singular aporía. Por un lado, dice, disfruto o soy capaz de vivir con sinceridad las pasiones efímeras («el devorante pétalo desarrollado en furia, / y el corazón labial del cerezo de junio»-con probable alusión al mes del Congreso), e incluso acepto o necesito la tranquilidad hogareña (leo en «el reposo de lentas barrigas que arden sin dirección» una oblicua referencia a su vida con Maruca).

Por otro lado, en los enunciados adversativos "pero me falta un suelo de cal con lágrimas / y una ventana donde esperar espumas» resuenan evocaciones nostálgicas del amor de Josie Bliss. El «suelo de cal con lágrimas» reitera elementos escénicos de la despedida final en los muelles de Colombo (1929), implícitos en el poema «Josie Bliss» «recientemente escrito» (poco antes del Congreso) y explícitos muchos años más tarde en las memorias del poeta, cuando recuerda el barco que está por partir: «besándome en un arrebato de dolor y amor, me llenó la cara de lágrimas. Como en un rito me besaba los brazos, el traje y, de pronto, bajó hasta mis zapatos [suelo], sin que yo pudiera evitarlo. Cuando se alzó de nuevo, su rostro estaba enharinado con la tiza [cal] de mis zapatos blancos... Aquel dolor turbulen- to, aquellas lágrimas terribles rodando sobre el rostro enharinado, continúan en mi memoria» (Neruda, 1999-2002, p. 501, p. 501).

$\mathrm{La}$ «ventana donde esperar espumas» evocaría en cambio la casa de Josie Bliss en Rangoon, cuyas ventanas son motivos recurrentes en los poemas de Residencia asociados a la amante birmana: «Porque la ventana que el mediodía atraviesa» («Diurno doliente»); «una casa de dos pisos con ventanas obligatorias» («Melancolía en las familias»).

\section{L'amour fou en Breton y en Neruda}

En los mismos días en que Neruda y Maruca desembarcan en Barcelona, a fines de mayo de 1934, André Breton conoce en París a Jacqueline Lamba (14 años menor). Exactamente el 29.05.1934, en el Café de la Place Blanche, ella está sentada escribiendo una carta sobre una mesa cuando llega Breton. La carta es para él. En verdad aquella muchacha, muy hermosa, ha buscado ese encuentro, y consigue seducir al escritor con su modo de hablar y la gracia de sus movimientos mientras juntos caminarán, toda esa noche, por las calles de París.

A ese encuentro seguirán el matrimonio en pleno verano (14.08.1934) y el nacimiento de una hija, Aube Solange, en diciembre 12, 1935. Durante estos dos años, y motivado por ese encuentro mágico al que siente haber estado predestinado recordando imágenes de su poema «Tournesol» (escrito en 1923, once años antes), Breton escribe L'amour fou, célebre texto iniciado a comienzos de 1934, antes del encuentro con Jacqueline, y que publicará en 1937. La primera intención era teorizar a fondo la concepción surrealista del amor, analizar su conexión con lo maravilloso y lo subversivo, afrontar los obstáculos que se oponen al amor absoluto, "convulsivo», y a su riqueza de posibilidades futuras. El encuentro con Jacqueline cambia la estructuración de L'amour fou, no sólo la vida de Breton. El automatismo psíquico (Manifiesto I, 1924) ya no es la única vía liberadora hacia el amor, hay otra vía exterior al hombre, quien sólo debe saber leerla: es el «azar objetivo» el modo en que convergen los íntimos anhelos del individuo y la realidad del mundo.

El relato del romance que nace en mayo de 1934 va a ser la modalidad con que una nueva concepción surrealista del amor, y la idea clave del azar objetivo, adquieren forma
Eva: la musa secreta de neruda en «Las furias y las penas» HERNÁN LOYOLA 
en el libro. Sólo que la realidad no se pliega fácilmente a la teoría. Jacqueline es pintora y sus propias ambiciones artísticas chocan crecientemente con el pasivo rol de musa (mujer-niña) que el poeta quiere imponerle. El conflicto entre la energía convulsiva que el surrealismo atribuye a la mujer y el papel vicario que le asigna dentro del proceso creador, estalla de hecho y no logra resolverse en el curso de la relación entre Breton y Jacqueline, hasta su separación en 1942.

Sin conexión con el surrealismo, desde 1923 -a través del abortado proyecto de $E l$ hondero entusiasta - Neruda busca también en la mujer el fundamento para su tarea poética, que en su caso es el proyecto de una "misión profética» que ella debería nutrir y sostener. No faltan en los poemas adolescentes de Neftalí Reyes indicios de una obsesión claramente conexa al desarrollo natural de su sexualidad, paralelo a su desarrollo cultural, específicamente literario. La sinceridad constitutiva de Neruda perseguirá, intransigente, la síntesis dialéctica de ambos desarrollos a lo largo de toda su trayectoria. Por eso en mi biografía del poeta, hasta ahora, esa persecución la he referido a su «sinceridad sexual», vale decir, a su esfuerzo por asignar al erotismo una categoría protagónica y fundamental dentro de la representación (o 'narración') de su tarea «profética». Lo que supone situar al erotismo «en el nivel alto de su escritura», no sólo de su vida, Su batalla obvia es contra la visión convencional, pero también -incluso en su período de adhesión al anarquismo- contra la transgresión fácil o gratuita o finalizada en sí misma. Hasta ahora (1935) no ha logrado una concepción totalmente satisfactoria al respecto.

Alguna vez (con Josie y con Matilde) Neruda asumirá honestamente la ilusión de haber alcanzado por fin aquella tan buscada síntesis (como Breton la suya con Jacqueline), pero a diferencia de Breton su búsqueda nunca perseguirá el Amor absoluto, el amor convulsivo liberado de ataduras, el amor por encima de la realidad y de la razón pragmática, el amor finalizado en sí mismo. Su íntima utopía era lograr para su vida la fusión de naturaleza y cultura (incluyendo en esta su propia escritura y la historia): como ya dicho, la unidad viva e interactiva del Yo y su Circunstancia, ambos naturales y a la vez historizados. La diferencia básica es que Breton, como Huidobro, partía desde programas o manifiestos, mientras Neruda partía desde su existencia personal, individual, hacia la integración activa y creadora con la realidad del mundo. De ahí que los éxitos y los fracasos (más o menos transitorios) de su búsqueda son elaborados en su escritura, sistemáticamente, con el tono, el sabor y los materiales de la experiencia vivida.

En Neruda l'amour fou busca escapar a la convención, pero no tanto en el plano de la trasgresión moral (como Breton y los surrealistas) cuanto en la exigencia de conectarse de algún modo a la transformación positiva de la realidad social, comunitaria. Desde Crepusculario a Residencia el rol transformador de una poesía eróticamente fundada asumió variadas formas de matriz romántica (véase Loyola, 2006, passim), con episodios de dramático conflicto y de auténtico heroísmo del poeta por fidelidad a su vocación profética. El caso más emblemático es la elaboración poética de la relación entre Neruda y Josie Bliss en Rangoon y en Colombo. Por lo cual sólo tenemos hasta ahora un itinerario de fracasos, siendo el último de ellos el que funda la escritura de «Las furias y las penas»:

$$
\begin{aligned}
& \text { Así es la vida, } \\
& \text { corre tú entre las hojas, un otoño } \\
& \text { negro ha llegado, } \\
& \text { corre vestida con una falda de hojas y un cinturón de } \\
& \text { [metal amarillo, } \\
& \text { mientras la neblina de la estación roe las piedras. }
\end{aligned}
$$

De la cólera inicial a la aceptación del fracaso, con un resignado adiós a la muchacha y a su inquieto destino. Los fracasos anteriores de Neruda han desembocado en el autoengaño (Albertina) o en la rendición a la norma (matrimonio con Maruca). La derrota representada en «Las furias y las penas» es por un lado la peor de todas, en cuanto obliga al poeta a aceptar la separación «erotismo/amor» en su vida con Delia, a quien ama de veras pero sin pasión. La prueba de la escisión es que no habrá en Tercera residencia ni en Canto general textos eróticos conexos a su amante argentina. (Por cierto, no le faltarán amoríos ocasionales durante los quince años sucesivos, previos a la irrupción definitiva de Matilde Urrutia en su vida y en su poesía.)

Pero por otro lado su amor a Delia no carecerá de sinceridad ni de importancia en el decisivo plano de la definición política de Neruda, vale decir, a causa de la intervención 
explícita de la Historia en la vida del poeta. La escisión «erotismo/amor» será aceptada de buen grado (o casi) por Neruda, y no sólo con resignación, con la 'ayuda' de la política oficial -notoriamente 'puritana'- del movimiento comunista (y de la cultura artística y literaria a él vinculada) respecto de la ética sexual y familiar, al menos durante la fase staliniana.

En suma, entre 1934 y 1935 l'amour fou de Breton se cumple o realiza, mientras desvanece en cambio l'amour fou de Neruda. Hay otras simetrías y oposiciones. En 1935 Breton cierra su 'militancia' comunista (que desde 1927 oscila entre Stalin y Trotski) con el bofetón que propina a Ilyá Ehrenburg poco antes del inicio del Congreso, por lo cual le será negado el derecho a intervenir y su discurso será leído por Paul Éluard, su entonces fiel amigo. Neruda, en cambio, justo durante aquel Congreso ingresa al área de acción de los comunistas.

El fracaso de la conjugación «erotismo/ amor» representada por «Eva» determina en la vida de Neruda una estabilización en la «norma», irónica esta vez, y más aparente que real, porque la convivencia con Delia del Carril será la base para el desarrollo revolucionario del poeta durante los sucesivos quince años. La «norma» equivaldrá a la «libertad» para el combatiente antifascista

\section{Epílogo: La Habana 1942}

El «diario» de Morla Lynch no trae ninguna alusión al viaje de Neruda a París, pero el 19.06.1935 registra en cambio, cuando ya el poeta ha partido:

Almorzamos en casa con Delia del Carril. Lleva una vida bohemia que se critica y su 'afinidad' con Pablo Neruda es muy comentada. Vive con él, su mujer y la niña enferma. Un drama que terminará mal.

En el Café del Correo pasa todas las noches con el grupo de Neruda, hasta la madrugada: entre otros, el músico Cotapos, el torero Amorós, el poeta-pastor Miguel Hernández, el dibujante [José] Caballero, Isaías Cabezón, el secretario de La Barraca Rafael Rodríguez Rapún y, a veces, Federico García Lorca. (Morla Lynch, 2008, I, p. 485)

Más adelante, el 06.07.1935, el diplomático registra una velada improvisada en su casa, presentes Pablo Neruda, Rafael Martínez Nadal, «el poeta-pastor Miguel Hernández, que ha venido con alpargatas, $y$ otro poeta mayor, León Felipe» (Morla Lynch, 2008, p. 486). Por esta anotación sabemos que Neruda ha regresado a Madrid, quizás esa misma mañana pues sólo al día siguiente, 7 de julio, escribe una carta a París que comienza así: "Chers Desnos et Youki: Je ne peux me pardonner encore de ne pas vous avoir téléphoné ce jourlà où nous partions. Ce jour-là a été satanique $\mathrm{du}$ commencement et rien ne nous a réussi. / Je me crois pardonné. Je vous ai envoyé mes adieux avec Carpentier» (de una carta inédita hasta su publicación en Vásquez, 1981, p. 56).

Neruda confiesa haber olvidado telefonear a los Desnos, y a la vez confiesa, implícita e involuntariamente, "no» haber olvidado visitar a Carpentier (y a Eva) para despedirse. Aún ardía aquel fuego. Líneas más abajo, la carta anuncia algo importante: «V. Aleixandre vous a envoyé, Robert, son livre. / Ne faillez pas de nous envoyer les vôtres. On va faire quelque chose. Maintenant adieu, chers amis, on est sûr de nous revoir en octobre. / Pablo Neruda». Esa "quelque chose" le será confirmada a Desnos dos meses después por el mismísimo Carpentier mediante una carta (también inédita antes de Vásquez, 1981, p. 57) fechada en Madrid el 11 de septiembre:

\section{Mon vieux:}

Pablo Neruda lance une revue de poésie à Madrid : CABALLO VERDE. Il veut de la collaboration de toi pour le premier numéro qui doît paraitre dans quelques semaines. Des poèmes si possible... ils paraitront en français.

Pablo Neruda me prie de t'écrire ces lignes. Inutile de te dire que nous comptons sur toi. Envois tes poèmes au plus vite à l'adresse suivante: Don Pablo Neruda / Meléndez Valdés 61 / Madrid / Espagne.

Ça va là-bas?

ton

Alejo Carpentier

De l'inédit, si possible!

Carpentier (seguramente con Eva) de nuevo en Madrid durante septiembre, de vacaciones, y de nuevo en contacto con Neruda. Contacto estrecho al punto que el escritor cubano se siente personalmente involucrado en la empresa Caballo Verde, según denuncia su «nous comptons sur toi» de la carta a Desnos. Con toda probabilidad Neruda se esforzó en intensificar el interés de Carpentier hacia la revista como vía para reencontrar -con decreciente ilusión- a la coqueta Eva. Tal vez a
Eva: la musa secreta de neruda en «Las furias y las penas» HERNÁN LOYOLA 
este período alude aquel «otoño negro [que] ha llegado» según las últimas estrofas de «Las furias y las penas», las que parecen proponer un final en disolvencia para la historia de la relación Pablo-Eva:

Corre con tus zapatos, con tus medias, con el gris repartido, con el hueco del pie, y con esas [manos que el tabaco salvaje adoraría golpea escaleras, derriba

el papel negro que protege las puertas, y entra en medio del sol y la ira de un día de puñales a echarte como paloma de luto y nieve sobre un cuerpo.

Es una sola hora larga como una vena, y entre el ácido y la paciencia del tiempo arrugado transcurrimos, apartando las sílabas del miedo y la ternura, interminablemente exterminados.

Con estos versos Neruda despide al erotismo de su poesía canónica durante los años de la elaboración de Canto General (hasta la reaparición en México de Matilde Urrutia), para concentrar las energías de su escrituraacción en la «praxis política» que, como ya quedó dicho, es la modulación que asume «lo profético que hay en mí» a partir del Congreso de junio en París.

Así en el terreno de la escritura. Pero en la realidad extratextual ¿termina allí la relación Pablo-Eva en su incandescente dimensión erótica? Imposible jurar sobre eso, primero porque con toda probabilidad se reencuentran en 1937 durante los meses de permanencia de Pablo y Delia en París. «Desnos y Youki vivían en el $n^{\circ} 19$, rue de Mazarine. Actualmente hay una placa de mármol al ingreso, donde se lee: Ici vécut / de 1934 à 1944 / Robert Desnos / poète français / Arrêté par la Gestapo et déporté / il trouva la mort parce qu'il était épris / de liberté de progrès et de justice». A poco más de 400 metros de allí, en un pequeño apartamento que (si no me equivoco) les buscó Desnos, vivieron $\mathrm{Pa}$ blo y la Hormiga con Rafael Alberti y María Teresa León. Estaba situada en el no 31, Quai de l'Horloge, y era vecino al de Carpentier» (comunicación de Enrique Robertson, mayo 2011). Neruda lo confirma en sus memorias, aludiendo a Carpentier («escritor francés») con el desprecio que le suscitó su adhesión a la «Carta abierta» de los intelectuales cubanos en 1966:
Llegamos a París. Tomamos un departamento con Rafael Alberti y María Teresa León, su mujer, en el Quai de l'Horloge, un barrio quieto y maravilloso. Frente a nosotros veía el Pont Neuf, la estatua de Henri IV y los pescadores que colgaban de todas las orillas del Sena. Detrás de nosotros quedaba la Place Dauphine, nervaliana, con olor a follaje y restaurante. Allí vivía el escritor francés Alejo Carpentier... (Neruda, 1999-2002, p. 534)

Y segundo, porque Pablo y Eva vuelven a encontrarse en La Habana, marzo-abril 1942, cuando Neruda logra realizar su anhelada visita a Cuba, donde desde 1939, como sabemos, vive Eva Fréjaville (ahora casada con el pintor Carlos Enríquez). Ya el 29.07.1940, navegando sobre el Yasukuni Maru que lo lleva hacia su destino consular en México, Neruda escribe unas líneas a Juan Marinello: «Me muero de ganas de ir a Cuba! Saluda a [Wenceslao] Roces, a Manolito Altolaguirre (a éste dile que me escriba), a Nicolás que me vaya a ver a México, a Pita (los dos), a Ballagas $y$ en particular a toda La Habana menos al viejo cabrón de Juan Ramón Jiménez» (Augier, 2005, p. 24). Pablo sabe que Eva está en La Habana, lo que es un poderoso incentivo. Presumo que por eso, en particular, muere de ganas de ir a Cuba.

Hasta ahora, aparte la respuesta «la mujer de Carpentier» que dio Neruda a mi pregunta sobre la identidad real de la destinataria interna de «Las furias y las penas», no he podido ofrecer al respecto otra documentación que los indicios ínsitos en el poema mismo y los datos que asocian tanto a Eva como a Neruda (pero separadamente) con Carpentier. El nombre de Eva no ha aparecido por ningún lado en conexión con Neruda. Aparecerá en cambio, finalmente, a raíz del viaje de Pablo y Delia a Cuba, confirmando que se conocían.

Manuel Altolaguirre y Concha Méndez vivirán un primer período de exilio en $\mathrm{La} \mathrm{Ha-}$ bana, entre la derrota republicana de 1939 y el traslado a México en 1943. «Durante su estancia en La Habana, los Altolaguirre habían hecho mucha amistad tanto con el pintor y escritor Carlos Enríquez (1900-1957) como con su esposa Eva Fréjaville. A Carlos Enríquez le publicaron su novela Tilín García (1939); a Eva Fréjaville, su ensayo Marcel Proust desde el trópico (1942)» (James Valender, en Altolaguirre, 2005, p. 440n). Neruda cuenta con los Altolaguirre para su reencuentro con la joven francesa (que ahora anda en los 29 años). 
Desde comienzos de 1941 Neruda intenta concretar su viaje a La Habana. Se conocen varias cartas suyas a Juan Marinello (quien promueve y organiza la visita de Neruda) que dan cuenta de sucesivas postergaciones a causa de dificultades económicas e imprevistos (como la agresión nazista sufrida en Cuernavaca). Postergaciones involuntarias, según subraya la carta del 16.10.1941: «Querido Juan: Recibí tu carta y quiero comunicarte que no desisto, ni desistiré nunca de mi proyectado viaje a Cuba, aparte de desearlo fervientemente es uno de los motivos principales por los que he venido hasta México [...]. Te agradecería muchísimo hicieras una gestión para que el Ministro de Cuba en Chile interceda cerca de mi Gobierno para que el viaje se realice...» (Augier, 2005, p. 27). De nuevo verificamos el tenaz, vehemente -y para mí «sospechoso»interés de Neruda en llegar a la isla.

Habiendo logrado ayuda económica de sus amigos cubanos, a comienzos de marzo 1942 Neruda obtiene un permiso de quince días «sin goce de sueldo» y se embarca con Delia en Veracruz sobre el vapor argentino Río de la Plata. Cuando la nave atraca en los muelles de La Habana el sábado 14 de marzo, allí los Neruda son recibidos por Juan Marinello, Nicolás Guillén, Ángel Augier, Enrique Labrador Ruiz, Luis Martínez Pedro y Manuel Altolaguirre. No he logrado documentación precisa sobre encuentros de Neruda con el matrimonio Enríquez-Fréjaville, tanto menos con Eva separadamente, pero que se frecuentan -por cuenta propia o a través de los Altolaguirre- lo testimoniará la misma Eva en carta del 13.04.1943 a los Altolaguirre (que en el entretanto se han trasladado a México) y en cuya parte final leemos: «Muchos besos a Hormiguita y abrazos a Pablo» (Altolaguirre, 2005, p. 443). James Valender pone al pie de la misma página la siguiente nota: «Eva Fréjaville habría tratado a Pablo Neruda y a su esposa Delia del Carril (La Hormiguita) durante la visita que éstos hicieron a Cuba en abril de 1942».

A Pablo no le faltan recursos para lograr un encuentro a dos con Eva, pero ya sabemos que la joven francesa es al mismo tiempo desprejuiciada y convencional, por lo cual quizás no pasó nada y su ex amante chileno se tuvo que contentar con la recolección de conchas marinas en Varadero y otras playas de Cuba, en compañía del que será su maestro en tal terreno, el ilustre malacólogo Carlos de la Torre. Pero hago notar la distinción en la frase de Eva: «Muchos "besos" a Hormiguita y "abrazos a Pablo" ", tal vez normal pero que en este caso me parece revelar en modo inconsciente, en vez de ocultar, el secreto ligamen que la une al poeta.

Hay más. En 1943 Neruda hace publicar en México un opúsculo titulado Canto general de Chile, que contiene algunos poemas de la futura sección VII del Canto general y que trae también, al final, el nutrido elenco de los suscriptores. Dicho elenco incluye nombres (cito sólo algunos) de españoles exiliados en Cuba y en México como Adolfo Sánchez Vásquez, los Altolaguirre, Ignacio Hidalgo de Cisneros, María Teresa León; de mexicanos como Alfonso Reyes, Adela Formoso Obregón de Santacilia, César Martino, Dolores del Río, Efraín Huerta; de chilenos como Diego Muñoz, Gabriela Mistral, María Luisa Bombal, Lola Falcón, Marta Brunet, Tomás Lago; de argentinos como Norah Lange, Sara Tornú, González Carbalho; de cubanos como Enrique Labrador Ruiz, Carlos de la Torre; y de otras nacionalidades como Ilyá Ehrenburg, Sara de Ibáñez, Miguel Ángel Asturias. Ahora bien: dispuesta según el orden alfabético de los nombres, la lista incluye entre los que comienzan por E una sorpresa: Eva de Carlos Enríquez. Como la distinción recién señalada en los saludos a Hormiga y a Pablo al cierre de la carta a los Altolaguirre, también el énfasis denuncia aquí algo que se quiere ocultar.

Así se cierra el círculo. Y «el resto es silencio». Hasta donde sé, este episodio amoroso con Eva Fréjaville fue uno de los secretos mejor guardados por Neruda. Como respecto a Malva Marina, tan extremo silencio -sumado a la escritura del poema «Las furias y las penas»- es índice de la importancia del personaje en la vida del poeta. Al menos durante aquellos años (1934-1942) en lo que concierne a Eva, la seductora Enemiga.

\section{Bibliografía}

Acosta, Leonardo (2008), «Literary material and lived experience in Los pasos perdidos», en $A$ Contracorriente, revista digital, North Carolina State University at Raleigh, vol. 5, no 3 , Spring.

Altolaguirre, Manuel (2005), Epistolario 1925-1959. Edición de James Valender. Madrid, Publicaciones de la Residencia de Estudiantes.
Eva: la musa secreta de neruda en «Las furias y las penas» HERNÁN LOYOLA 
Augier, Ángel (2005), Pablo Neruda en Cuba y Cuba en Pablo Neruda. La Habana, Ediciones Unión.

Aznar Soler, Manuel (1987), Primer Congreso Internacional de Escritores para la Defensa de la Cultura - Paris 1935. Valencia, Generalitat Valenciana, 2 vols.

Campuzano, María Luisa, (2006), «Mujeres y papeles: Ruth y Mouche en el taller del escritor», en Cuadernos de Literatura, vol. XI, no 21, Bogotá (julio-diciembre 2006), 14-26.

Gibson, Ian (1987), Federico García Lorca. II: De Nueva York a Fuente Grande (19291936). Barcelona, Grijalbo.

- (2009), Lorca y el mundo gay. Barcelona, Editorial Planeta.

González Echevarría, Roberto (2008), Cartas de Carpentier. Madrid, Editorial Verbum.

Loyola, Hernán (1987), «Introducción» y notas a Pablo Neruda, Residencia en la tierra, edición crítica. Madrid, Cátedra, varias reimpresiones.

- (2006), Neruda. La biografía literaria / Vol. I: La formación de un poeta 19041932. Santiago de Chile, Planeta-Seix Barral.

Morla Lynch, Carlos (2008), En España con Federico García Lorca. Sevilla, Editorial Renacimiento.
Neruda, Pablo (1999-2002), Obras completas, edición y notas de Hernán Loyola, 5 vols. Barcelona, Galaxia Gutenberg \& Círculo de Lectores.

Pogolotti, Graziella, (2006), «Zizou», en Revolución y Cultura, Época V, $\mathrm{n}^{\circ} 1, \mathrm{La}$ Habana.

Pogolotti, Marcelo (1968), Del barro y las voces. La Habana, Ediciones Unión.

Robertson, Enrique, (2009), «¿De qué murió César Vallejo?», en Nerudiana n 7, Santiago de Chile (agosto 2009), 24-25.

Sáenz de la Calzada, Luis (1976), La Barraca. Teatro Universitario. Madrid, Biblioteca de la Revista de Occidente.

Sánchez, Juan (2005), Carlos Enríquez. La Habana, Editorial Letras Cubanas.

Santí, Enrico Mario (2005), «Memoria de la mitomanía: Centenario de Alejo Carpentier / Entrevista con Eva Fréjaville», en Linden Lane Magazine, vol. XXIV, $\mathrm{n}^{\circ}$ 1-4, 13-16.

Vásquez, Carmen (1980), «Alejo Carpentier en París (1928-1939)», en Culturas, vol. VII, no 2, UNESCO, París (1980), 172 184.

- (1981), «Pablo Neruda y la revista Caballo Verde para la Poesía», en Revista de Estudios Hispánicos, año VIII, San Juan de Puerto Rico, 55-65.

Fecha de recepción: 01/07/2011 Fecha de aprobación: 10/10/2011 